\title{
The Triple Helix model of Silicon Valley and Ecuador
}

\author{
Yolanda E. Ledesma ${ }^{\text {iD }}$, Ángel R. Cobos \\ Universidad Central del Ecuador, Ciudadela Universitaria, Av. América, Quito, Ecuador. \\ Autores para correspondencia: yoli_ec@yahoo.com, rodrigo.cobos537@gmail.com \\ Fecha de recepción: 19 de septiembre 2016 - Fecha de aceptación: 20 noviembre 2016
}

\begin{abstract}
Silicon Valley emerged as a center of research and innovative technological development. The unprecedented success of Silicon Valley is a result of the interaction between the structural transformation of technology and economic resources, and the social, cultural and institutional conditions of entrepreneurship. Ecuador created recently the City of Knowledge "Yachay"; named the "Ecuadorian Silicon Valley". The objective of this paper is to analyze the Government-Industry, Government-University, and University-Industry interactions in Silicon Valley and Ecuador in general, as basis for the identification of achievements and gaps. First, a brief review of the historical evolution of Silicon Valley during its 70 years of existence is given, highlighting the amazing and unexpected growth and technological and economic progress. The methodology used in this article is the Triple Helix model enabling to analyze the interactions between the three sectors: Government, Industry, and University. The initial double helix Government-University and University-Industry interactions in Silicon Valley converged over time into the triple helix University-Industry-Government relations. This article identifies the limitations of the relationships and suggest the strategies that the Ecuadorian government should pursue and implement the ones that lead the Valley to success. Ecuador is now trying to develop a knowledge economy in anticipation that someday its economy based on natural resources might dry up.
\end{abstract}

Keywords: Ecuador, economic development, technologic development, knowledge economy, city of knowledge, Silicon and Yachay Valley.

\section{RESUMEN}

Silicon Valley surgió como un centro de investigación y de conocimiento tecnológico innovador. El éxito sin precedentes de Silicon Valley es el resultado de la interacción entre la transformación estructural de la tecnología y los recursos económicos, así como las condiciones sociales, culturales e institucionales de la iniciativa empresarial. Ecuador ha creado la Ciudad del Conocimiento 'Yachay' que también es conocida como el "Silicon Valley Ecuatoriano". El objetivo de este trabajo es analizar las interacciones Gobierno-Industria, Gobierno-Universidad, y Universidad-Industria, con el fin de identificar sus logros y problemas. Primero, es necesario comenzar con una revisión de la evolución histórica de Silicon Valley durante sus 70 años de existencia, destacando el crecimiento sorprendente e inesperado y el progreso tecnológico y económico que ha comenzado una nueva era tecnológica en todo el mundo. La metodología utilizada en este artículo es el modelo Triple Hélice que pretende analizar las interacciones entre los tres sectores: El gobierno, la industria y la universidad. La doble hélice de interacciones iniciales Universidad-Industria y Gobierno-Universidad de Silicón Valley convergieron en relaciones triple hélice Universidad-Industria-Gobierno con el tiempo. Este artículo identifica las limitaciones de las relaciones y también sugiere las estrategias que el gobierno ecuatoriano debe adoptar con el fin de imitar e implementar aquellas que condujeron a Silicon Valley al éxito. Actualmente, el Ecuador intenta desarrollar una economía del conocimiento mediante la construcción de su propia versión de Silicon Valley debido a que su economía se basa en los recursos naturales que se agotarán algún día. 
Palabras clave: Ecuador, Desarrollo económico, Desarrollo tecnológico, Economía del conocimiento, Silicon Valley.

\section{INTRODUCTION}

It is vital to summarize the historical development of Silicon Valley to understand its evolution during its 70 years of existence. The region is characterized for having had an amazing and unexpected growth, technological and economic progress. It has marked a milestone, and a new technological era. Frederick Terman, Vice-President of Stanford University and the founder of Stanford Industrial Park, provided the link between the early stages of electronics, $R \& D$ and manufacturing, and the formation of Silicon Valley, regarded as the true ancestor of all world's existing and future technopoles.

According to Castells \& Hall (1994), Silicon Valley has experienced five remarkable stages that lead to its development. These stages include:

1) Technological innovations achieved during the first half of the twentieth century.

2) High technology industry formed at the Stanford Industrial Park in the 1950s.

3) The growth of innovative microelectronic firms with electronic based programs supported by the Department of Defense in the 1960s.

4) The consolidation of microprocessors based on semiconductors, and the launching of the personal computer era in the 1970s.

5) The domination of the computer industry, its innovative spin-offs, and the internationalization of the industrial structure, in the 1980s.

Silicon Valley, located in San Francisco, California, began with the invention of the vacuum tube by Deforest in 1912 for the Federal Telegraph Company. Terman created the Stanford Industrial Park in 1951. Then, some recognized firms, such as Valian and Hewlett-Packard moved to Silicon Valley in 1954 and 1960, respectively. William Shockley, Nobel Prize winner and co-inventor of the transistor in 1947, together with Bell Laboratories in New Jersey, founded Fairchild Semiconductors in 1965. This company was the only transistor firm to work exclusively in Silicon Valley, and lead directly or indirectly to the creation of 45 out of the 85 major American semiconductor firms. Half of them settled down in Silicon Valley between 1959 and 1976, such as Amelco, Intel, Advanced Microdevices, Signetics, and National Semiconductors, among others. Another important factor to consider was the significant military demand for electronic devices in the 1960s.

Computers and services in hardware and software firms were generated as a result of the emergence of the PC by IBM in 1981. Sun Microsystems was one of them, which became the most important production activity in the Valley, even surpassing semiconductors. In the first half of 1980s, 21,000 workers were laid-off by the computer industry in Silicon Valley as consequence of the world downturn and Japanese competition. Fortunately, social networks contributed by generating new companies in the second half of this decade. In this way, Silicon Valley stood out in microelectronics and computers and became a self-sustaining innovative environment of high technology manufacturing and services (Castells \& Hall, 1994).

Silicon Valley is one of the most successful technopole's in the world. "Smart infrastructure" played an important role in fostering these high-technology growth poles in the last five decades (Gouvea \& Kassicieh, 2012). The key factors in the fostering and creation of technopoles is a combination of venture capital, know-how, talent, and a modern and efficient physical infrastructure, such as science parks and incubators (Cristoni, 2010, cited in Gouvea \& Kassicieh 2012). Given this it is likely that a high-technology start-up will have more success in highly developed countries than in emerging economic countries (Zoltan, 2005).

The Ecuadorian government created in 2014 the City of Knowledge "Yachay". Yachay means knowledge in Kichwa. It is called the Ecuadorian Silicon Valley by many people, due to the way innovation and knowledge are managed (Araque, 2013). The University of Experimental Technology Yachay, within the City of Knowledge Yachay, is located on San Miguel de Urcuquí, in the state of 
Imbabura, occupying a total area of 4,439 hectares. Yachay Tech University implements an advanced quality model based on high academic standards of education, research and spinoff. The model assures that its academic programs receive international accreditation and recognition. It also facilitates social interaction, public investment in infrastructure, sustainable mobility and connection to the Information and Communication Technology sector. Its purpose is to integrate and optimize human and physical capital in order to generate new knowledge that improve the lifestyle of all Ecuadorians and comply with the National Plan for Good Living.

\section{METHODOLOGY}

The methodology used in this article is the Triple Helix. The Triple Helix model was created by Etzkowitz \& Leydesdorff (1995) with the purpose of analyzing the interactions between the three sectors: Government, University and Industry (see Figure 1).

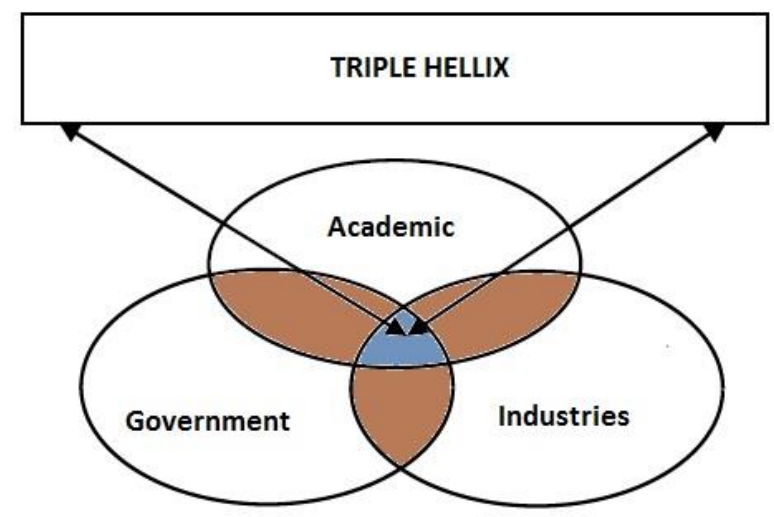

Figure 1. Triple Helix model (Source: Etzkowitz \& Leydesdorff, 1995).

\section{RESULTS}

This section provides an analysis of the Triple Helix approach in Silicon Valley and Ecuador, with focus on the Government-University, the Government-Industry and the University-Industry relationships, and the identification of the contributions and gaps of each relationship to innovation, technology and knowledge.

\subsection{Government - Industry relationship}

Etzkowitz (2011) argues that Silicon Valley initially emerged as an entrepreneurial university engaged with industry and government, result of Stanford University's development strategy. This made Stanford University a world-class institution. Its university partners are Stanford, San Jose State, Santa Clara, and Berkeley. These partners played an important role in the industry by providing the labor market with well-trained engineers and scientists, as well as cooperative research programs that link them to the firms. Moreover, the endogenous research capacity of the industry was substantial in the regional R\&D development (Castells \& Hall, 1994).

In the case of Ecuador, investments have been directed to education, information and communication technology (ICT), telecommunications, scientific development and renewable energy. With respect to education, the Ecuadorian government planned to invest 1,100 million dollars in four main centers, spread over the period 2013-2017. These centers are: the city of knowledge "Yachay" for scientific research; the National University of Education for teacher training (UNAE) in Azogues; the University of Arts in Guayaquil (UArtes); and the University for Life Sciences (Ikiam) in Tena. Their 
goal is to drive as much technological innovation and business-related knowledge to boost the country's productivity and economic growth. The focus of those centers of excellence is not only on education, but also on the development of research and the intense cooperation with the academic and industrial sector to make them accountable to Ecuador's society of the $21^{\text {st }}$ century. In an initial phase the focus of those 4 centres is the development of highly qualified graduates as basis for the future scientific and technological development of the industrial sector and the society, and to contribute to a strengthening of the relation between government, university and industry. In a second phase, when those centers acquire maturity in investigation and recognition at national and international level, it is to be expected that this will result in a more intensified cooperation between these centers, Ecuador's leading public and private universities, and the industry under the impulse of the government (Toasa, 2015).

According MINTEL (2014) is the lifestyle of citizens positively affected by the implementation of public policies stimulating the development of industry and the use of ICT. Consistency over the last 10 years of those policies resulted in an overall improvement of Ecuador's ranking at international level. Figure 2 depicts Ecuador's position for $10 \mathrm{NRI}$ indicators ${ }^{1}$ with respect to the average position of the upper-middle income countries.

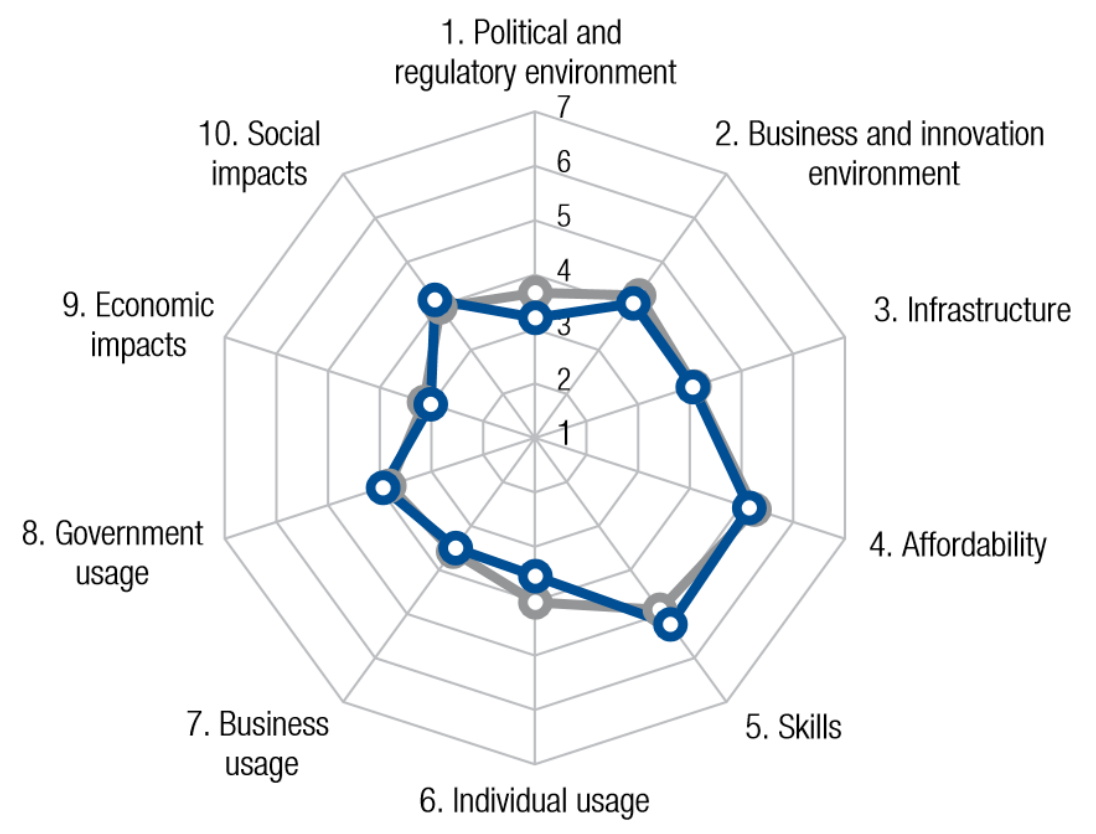

Figure 2. Ecuador's position for $10 \mathrm{NRI}$ indicators (blue line) with respect to the average position of the the upper-middle-income countries (gray line) in 2016 (Source: http://www3.weforum.org/ docs/GITR2016/WEF_GITR_Ecuador_2016.pdf).

Figure 2 shows the economy's performance in terms of the overall networked readiness index (NRI), composed based on four main components, 10 pillars, and a 1-to-7 scale to score the economy's rank among 139 countries. The blue line depicts Ecuador's position in comparison to the group average of the upper-middle-income countries, a group to which Ecuador belongs. The NRI uses 53 indicators, organized by pillars, which summarizes the economy's performance of a given country, in this case Ecuador. According to Baller et al. (2016), Ecuador scores 82 out of 139 countries according to the NRI metric with a value of 3.9 out of 7. In comparison, Chile's position is 48 with a value of 4.6 , corresponding to the average NRI value of the high-income group of countries, while Guatemala ranks 103 with a value of 3.5 , corresponding to the average value of the lower-middle-income countries. Ecuador's economy is positioned in the middle of the economies of Latin American countries.

1 NRI indicators: Networked Readiness Index indicators (World Economic Forum, http://reports.weforum.org/global-information-technology-report-2016/) 


\subsection{University - Industry relationship}

Analysis of the University - Industry relationship reveals that continuous innovation enhances and sustains economic strength. For example, the United States, Japan and some European countries are worldwide leaders in economic development thanks to the continuous high investments in R\&D, which on its turn results in an equivalent large number of patents (Pervaiz et al., 2012). The United States of America registered in 2014578.802 granted patents or inventions, including 167.000 granted patents to foreign residents. Just Silicon Valley registered 37.6\% $(217,630)$ patents $(2014)$. Ecuador registered in the period 2000-2007 only 387 patents, equivalent to $0.007 \%$ of the American's technological annual production. Among Ecuador's structural and system indicators, the best rated are the social value of science and technology, and the services offered to citizens, while the worst rated are the global workforce dedicated to I+D and the number of patents. Of every patent registered per year by Ecuador, only $5 \%$ are nationals and $95 \%$ are in the pharmaceutical field. So far, only 5 Ecuadorian universities recorded a total of 8 patents (Instituto Ecuatoriano de Propiedad Intelectual, 2016). The Ecuadorian government has the ambition to stimulate the production of patents in the coming years.

In addition, to a strengthening of the interaction between universities and industry, it is important that parallel a sharing of technology and knowledge take place with public research institutions, the federal state and local governments, and the private sector (Melkers et al., 1993, cited in Phillips, 2002). Walsh \& Kirchhoff (2002) argue that technology transfer to some degree automatically occurs internally in all organizations and between manufactures, vendors, and customers. Additionally, those authors stated that any technology transfer model must include a high degree of interaction and communication. Technology transfer can be defined in different ways, and according to Phillips (2002) is the transfer of technology "the licensing of technology from a university to an incubator client firm", whereas Powers \& McDougall (2005) define university technology transfer as a "process of transforming university research into marketable products".

Today, it is generally accepted that the growth and welfare of societies lies in innovation. In this regard, Ecuador created the Alliance for Entrepreneurship and Innovation (AEI) to support firms to foster innovation. The alliance encompasses 21 public entities, the private sector and the academia. To realize its objective, the alliance urges that the gap between universities and industries must be reduced. This assertion is based on the fact that the universities in Ecuador do not transfer knowledge to the industry and vice versa the industry does not incorporates new knowledge into its business model (Revista Líderes, 2015). To enhance competitiveness and efficiency of their operation the Ministerio de Telecomunicaciones y de la Sociedad de la Información (MINTEL) is convinced that the scientific and technological level of their activities be increased via de linking of activities to research and innovation. MINTEL (2014) claims the following about the I+D+i situation in Ecuador:
"With respect of the academic system, its best potentialities are observed in the percentage of university population and the quality of graduates. The weakest points are in the number of publications and the number of PhD-holders. In relation to Ecuador's entrepreneurship capacity, the least highlights are the shortage of staff dedicated to $I+D$ and the lack of university-industry collaboration. Among the structural and system indicators, the best rated are the social value of science and technology, and the services offered to citizens, while the worst rated are the global workforce dedicated to $I+D$, and the number of patents."

\subsection{Government - University relationship}

Silicon Valley clearly showed that innovative companies to take root in a region, the funding of university research and the development of science parks is insufficient (Wessner, 2014). Lucas (1988) states that to develop and launch new products and companies, it requires the collaboration of investors, researchers, and entrepreneurs. Moreover, knowledge, relationships, and motivation are core elements to secure the competitive advantage against other regions, and communities (Porter, 1998).

Given the overall low to moderate level of the knowledge of Ecuador's society, the first occupation of the government with respect to the higher education sector and the four recently established public institutions (Yachay Tech, Ikiam, UNAE and UArtes) should be focused on reducing the technological gap by stimulating the change of the productivity matrix (Toasa, 2015). To achieve this purpose with time, it is important to strengthen the capacity of the higher education system by hiring international 
creative, innovative and well trained people, who can create, redesign and implement new technologies in close cooperation with the local academic community, the industry and the government. In this regard, the Ecuadorian government provides scholarships to junior citizens to acquire abroad a third (master) or fourth $(\mathrm{PhD})$ level degree in leading universities and attracts overseas experts to assist local institutions to develop and improve their research capacity (National Secretariat of Planning and Development, 2016). In this regard, the Prometheus Project, created in 2010 by the Ecuadorian government, aims the innovation of Ecuador's higher education system by strengthening teaching, research, and the transfer of knowledge on specialized topics by incorporating local and foreign experts in order to contribute in areas related to: education, innovation, life sciences, art, natural resources, culture, production, and social sciences (Prometeo, 2016). This assistance will help public research institutes, universities, polytechnics, and other public institutions to develop research projects - and hopefully the production of patents - in the country's priority sectors.

Powell \& Snellman (2004) define the knowledge economy as "production and services based on knowledge-intensive activities that contribute to an accelerated pace of technical and scientific advance, as well as rapid obsolescence." Arnal et al. (2001) states that globalization and technological advances are the factors for the emergence of the knowledge economy, which has increased the demand for higher levels of competencies among workers. This kind of competencies are called workplace competencies which are responsible for economic growth. Knowledge workers rely on workplace competencies. These competencies include the ability to use information and communication technologies (ICT), team work, leadership, problem solving, organization, and continuous learning.

Differences in the Triple Helix approach between Silicon Valley (USA) and Ecuador can be best illustrated based on the following statistical data. Ecuador's population amounts 16,279,000 people, equal to $5 \%$ of the United States' population $(321,234,000)$, and Silicon Valley counts $6,818,627$ people, equal to $42 \%$ of Ecuador's population. The per capita income of Silicon Valley is $\$ 63,288$ while the per capita income of Ecuadorian citizens is on average $\$ 10,720$, which is $17 \%$ of Silicon Valley's income per capita and $20 \%$ of the average per capita income of the United States (Banco Mundial, 2015). Ecuador's GDP is $\$ 100,200$ million (2015), which is $0.6 \%$ of the United States' GDP $(\$ 16,768$ billion in 2014). American's GDP annual growth rate fluctuates around 3\% while in Ecuador the GDP annual growth rate dropped from 1.5 to $2.0 \%$ in the period 2010-2014 to a rate of $0.3 \%$ in 2015 (The World Bank, 2016). It is to be expected that Ecuador's GDP growth rate will further decline and be negative in $2017^{2}$. The United States of America is investing 2.79\% of its GDP ( $\$ 467,827$ millions) in science and technology, $\$ 100$ million of which is invested in research at universities and national laboratories. In contrast, Ecuador has projected to invest $0.55 \%$ of its GDP ( $\$ 550$ millions) in science and technology. Despite Ecuador has a slow growth and a very low reinvestment rate (3.5\%), the current government is committed to reinforce the technological development. Silicon Valley provides 387,000 high-tech jobs, which is greater than the 296,000 highly skilled professionals demanded in Latin America. The demand for Ecuadorian professionals with skills in networking and Information Technology and Communications increased in 2015 from 27 to 35\%. It is the government's dream that in 2043, 30 years after the foundation of Ecuador's Silicon Valley, Yachay Tech city will be converted into a high-tech city, burgeoning 100,000 citizens and housing a variety of factories in the nanotechnology, oil, the pharmaceutical and the ICT sectors (Wyss, 2014).

However, Silicon Valley is not so easy to be replicated by Ecuador, and this for the following reasons:

1) Time: Silicon Valley is the oldest high-tech community in the world; started seventy-five years ago.

2) Location: Silicon Valley benefited greatly from Americans migrants, the new jobs in aerospace and electronics.

3) Infrastructure: A wide range of educational institutions participated in the transfer of knowledge.

2 http://www.tradingeconomics.com/ecuador/gdp-growth 
4) Culture: Its culture is characterized by risk-taking, information sharing, one-to-one networks, openness to new ideas, and diversity.

Furthermore, Silicon Valley could rely throughout his history on the influx of sufficient venture capital, which secured the continuous injecting of capital in the development and diversification of innovative industrial activities. Important to notice thereby is that the venture capital of private and public institutions often acted as bridges for the establishment of links and cooperation between local and multi-national companies, anticipating innovation and the commercialization of new marketable technological products (Lall, 2004; Figueiredo, 2008). According to Malecki (1997), other regions in the U.S. tried to imitate the rhythm of Silicon Valley, like Route 128 (Boston) by creating high tech jobs in different locations but without the dynamism of high-tech centers. Today, the American government is developing strategies to promote the formation of new clusters at different locations in the country.

The Ecuadorian government should implement the following activities in order that the utopia city of Yachay Tech, Ecuador's Silicon Valley, turns into a business-friendly environment, where entrepreneurship and innovation can thrive, and becomes the backbone of Ecuador's technological profile:

1) Low levels of technological productivity, reflected in low levels of sales and income makes the industry most vulnerable to external competition. To combat this, policies should be in place resulting in a strengthening of a technological advanced industrial sector, complementing stepwise Ecuador's current industrial sector, which almost entirely is focused on the processing of natural resources, involving intensive labor and low levels of technology.

2) Providing the environment that will result soon in a satisfaction of the current and future demand of professionals with skills in networking and ICT. As stated by Pineda \& Gonzalez (2016) amounted in 2015 the total essential networking skill gap index in Ecuador 39\%, and the estimated gap will still be $25 \%$ in 2019 . This gap evidently hinders and slows down the technological conversion of Ecuador's economy.

3) Increase the investment rate in science and technology from $0.55 \%$ of the Gross Domestic Product (GDP) to at least 1\% until 2020, following UNESCO's recommendation; and foresee even thereafter the injection of a larger percentage of GDP in both sectors, to assure that Ecuador's industrial sector becomes and remains innovative and competitive.

4) Increase the budget for research in universities and research centers to at least $11 \%$, like the American universities; but develop at the same time strategies that forces universities and research centers to increase among them cooperation, the elimination of duplications, become more effective and meaningful. In this regard, it is more than wishful that the newly founded centers of excellence (Yachay, Ikiam, UNAE and UArtes) cooperate in their research endeavors with the country's leading public and private universities, as to have the widest possible geographical impact on the country's industrial development.

5) Optimize and simplify the heavy bureaucracy in public universities so that the institutions can spend the received R\&D funding up to 100\%, since in the period 2010 to 2012700 million of their committed budgets was underspent because of the paralyzing effect of administrative constraints.

6) Increase the number of academic staff in the public and private universities holding a $\mathrm{PhD}$ degree by providing to junior staff and professors grant possibilities that enable them to acquire abroad a third (MSc) or fourth level (PhD) degree. In parallel, provide to Ecuador's top universities, for example the institutions in category A, the permission to organize under well controlled conditions master of science and doctoral programs. Both measures, given the higher education institutions put into the recruitment criteria of staff the condition that candidates hold a doctoral degree, will result with time in an increase of the $\mathrm{PhD}$ holding academic staff. Universities of excellence should have, according the Higher Education Council (CES), at least $11.5 \%$ of the academic staff holding a PhD-degree. Despite the low level of this goal, it is an objective not yet accomplished.

7) Stimulate the academic community to be more engaged in research and to contribute in a more effective way to the country's publication visibility at international level. For the time being the backlog in the writing culture of Ecuador's top-10 polytechnic schools and universities, with 
respect to leading South American universities is on average 20 years, and 50 years relative to western European research and technologic oriented academic institutions (Feyen et al., 2016).

8) Making the higher education institutions more accountable. University's and Polytechnic School should optimize the nexus between teaching, research and services, and prepare young people for jobs in a growing knowledge economy. In this respect, Latin America is clearly lagging.

9) Create the environment that results in an increase in the number of granted patents at national level from 387 in the period 2000-2007 to at least 578 per year, which would be $0.01 \%$ of the American technological production, especially stimulating the university's role with respect to the development of patents.

To quantify the advances in the development of the relationships in the Triple Helix, it is advisable to use the GEDI index (Global Index Entrepreneurship and Development) (Dueñas \& Duque, 2015). This index allows to define the differences in business creation (new ventures), risks, competition, and the business' returns at national and international level (Barreto \& Jara, 2015; Zoltan \& Correa, 2014). The GEDI index expresses the entrepreneurial attitudes, abilities and aspirations of the local population and weights these against the prevailing social and economic infrastructure. It is evident that the value of the GEDI index is affected by the relationships between the government and the university, the university and the industry, and the industry and the government. Among the Latin American countries, Brazil has a better score than Mexico and Argentina, but a lower score than Chile. Ecuador's GEDI amounts $27.4 \%$, and is located $14^{\text {th }}$ in the regional rank and $88^{\text {th }}$ in the world rank. The GEDI index is based on the country's score on 14 pillars. Figure 3 reveals that Ecuador's score is above the average world and regional level in opportunity perception (0.57) and start-up skills (0.63), while the country has a lower score in internationalization (0.06) and tech sector (GEDI, 2016).

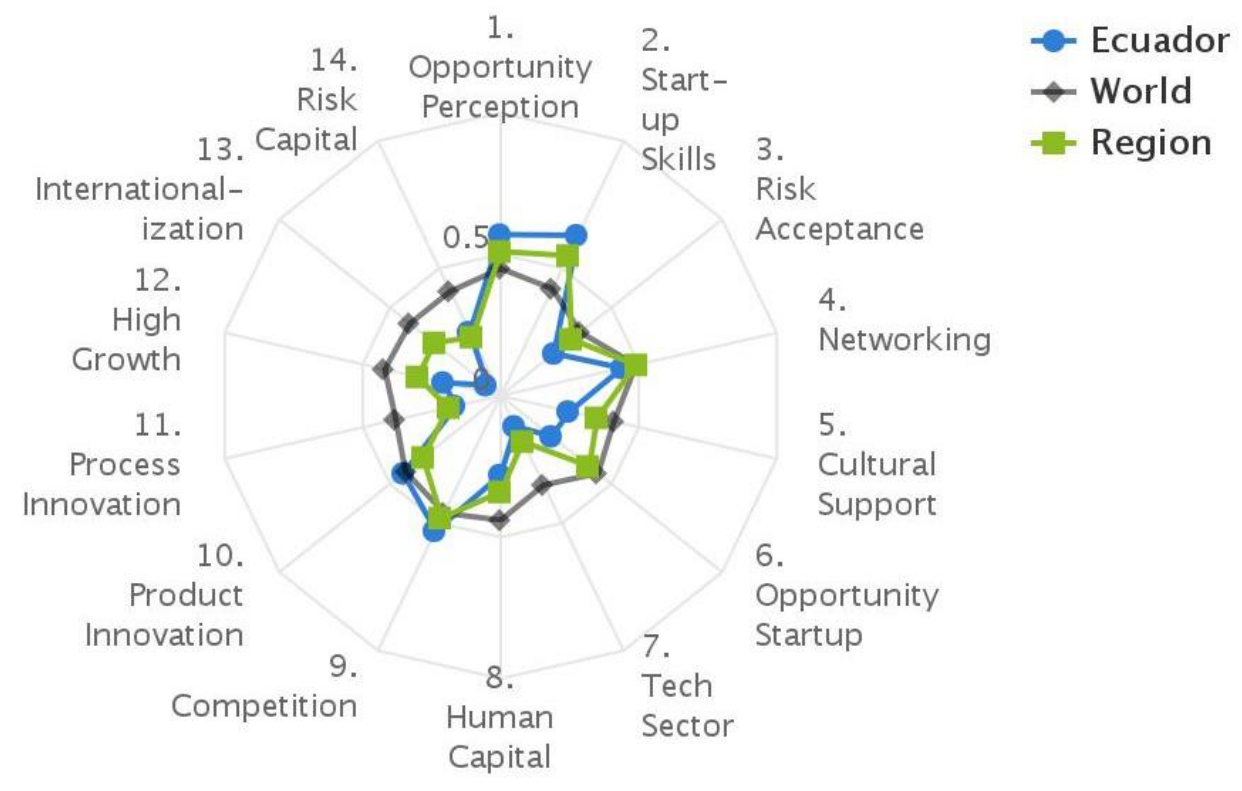

Figure 3. Ecuador's score on the 14 pillars which together define the country's GEDI rank in comparison to the regional and world average levels (Source: GEDI, https://thegedi.org/ countries/Ecuador, 2016).

\section{DISCUSION AND CONCLUSIONS}

Analysis of the Triple Helix innovation approach of Silicon Valley reveals that the initial double helix "government-university" and "university-industry" relationships converged with time into a triple helix 
university-industry-government relationship. Indeed, based on the region's history, the socio-economic framework in the Valley evolved from a local generator of new technologies and industries into the key node of a global network (Etzkowitz, 2011). It is Ecuador's aspiration to develop by 2043 Yachay Tech, analogue to Silicon Valley, be it at a smaller scale.

The global network in Silicon Valley includes multi-national firms; the involvement of regional and national governments; and the connection with universities, the sources of advanced technologies, as detailed in the following:

1) The first helix, Government-Industry, was the result of Stanford University's development strategy as an entrepreneurial university engaged with industry and government. The current state of innovation in the government of President Rafael Correa improved substantially the development of technology and knowledge management, but the situation is still in its infancy. Given current policies and strategies survive future political changes and the fluctuation in GDP annual growth rate, which since 2014 is in a downward spiral, it is likely that Yachay Tech will play in Ecuador a similar role as Silicon Valley did and still does in the U.S.

2) The second helix, University-Industry, is materialized by the U.S. university partners that secured the delivery of professionals to the labor market and cooperative research programs to the industry and firms, which enhanced the R\&D development of the region with positive effect on the industry. In the case of Ecuador, it is essential that the universities develop knowledge and transfer this knowledge to the firms, and the companies ought to make intensive use of this new knowledge to improve and diversify the range of economic outputs. Furthermore, it is recommended that universities become more entrepreneurial, and develop a product oriented working together culture with national and international HEIs and the local industry.

3) The third helix, Government-University, in the U.S. focused and aimed at promoting the transfer of technology and knowledge not only among the industry and the university, but also to public research institutions, the federal, state and local governments, third party intermediaries, and the society at large. The Ecuadorian government created the City of knowledge Yachay Tech, which some consider the first hub of knowledge in Latin America. Parallel to the foundation of Yachay Tech, three other public universities were created, which as Silicon Valley and Yachay Tech will adopt for their operation the Triple Helix model, linking the university with public and private institutions, high-tech firms, agriculture companies, and industries.

Some similarities, but also some differences can be found in the Triple Helix model applied by the Silicon Valley and Ecuador. The main similarity between Silicon Valley and Ecuador is that the creation process is similar, ambitious, committed and reinvesting. However, Silicon Valley is given its 70-year old history and its location in the United States worldwide well known as a center of science and technology, whereas Yachay Tech notwithstanding its recent establishment possesses striking similar long-term aspirations be it at a smaller scale; it is to be known at regional and national level as a hub of scientific research and interdisciplinary engineering. Silicon Valley's R\&D centers are more oriented to development, Yachay Tech focuses on the promotion and development of scientific research, the production and dissemination of knowledge, and the creation of national and international networks of knowledge in life sciences, ICT, nanoscience, energy and petrochemistry. The four key factors that led Silicon Valley to success are respectively: firm strategy \& company rivalry, factor input conditions, demand conditions, and related \& supporting industries (Porter, 1998). The factor input conditions include: active cooperation between universities, $R \& D$ firms and trade associations, the presence of leadership and decision making capacities at the level of the organization, the university and research institutions, and modern infrastructure. Other factors include: government influence, private financing, location, economics, and technological advancements. Because all these factors, Silicon Valley emerged as the world leader in IT clusters. In contrast, Rao \& Scaruffi (2011) argued that:

Silicon Valley is largely viewed as the symbol of ... revolution [in computing and telecommunications]. However, computers were not invented in Silicon Valley and Silicon Valley never had the largest hardware company, nor the largest software company in the world. Silicon Valley did not invent the transistor, did not invent the integrated circuit, did not invent the personal computer, did not invent the Internet, did not invent the World-Wide Web, 
did not invent the browser, did not invent the search engine, and did not invent social networking. Silicon Valley did not invent the phone, did not invent the cell phone, and did not invent the smart phone. But, in one point in time or another, Silicon Valley was instrumental in making them go "viral".

Based on the above findings, the following recommendations are made for Ecuador to improve its competitiveness as well as its Triple Helix of Innovation. For the time being, the Ecuadorian government is granting scholarships to students and professionals to improve their academic capacity and skills. To assure the long-term benefit of this investment the government should deploy strategies that prevent brain drain and integrate those capacities in the government, the academic sector and industry. Doing so will automatically enhance the relationship between those three pillars and result with time in the development of Ecuador's knowledge society, which will consist of universities of excellence, business incubators, research parks, knowledge based high tech companies, strong entrepreneurial professional services and a supporting government. The projected value by the Ecuadorian Government in relation to the future investment in innovation, technology and knowledge is $0.55 \%$ (550 millions) of the GDP (100.9 mil millions in 2015); although the current value fluctuates around $0.38 \%$ (380 millions) of the GDP. The projected value assigned to R\&D is still modest and small compared to the investment level in R\&D by other countries; for example the U.S. dedicates $2.81 \%$ of its GDP to R\&D, Japan 3.47\% and Brazil 1.15\% (The World Bank, 2016). Parallel to an increase in $R \& D$ funding it is important in order that new knowledge and developments benefices the wider society that the scientific community develops intensive relationships among knowledge producing institutions, with the industry and professionals, and that they continuously upgrade their knowledge. Professionals are key persons in the transfer of knowledge and new technologies in the wider production process of firms, companies and the industry.

It is desirable that in future the allocation percentage of 0.55 of the GDP to research and development is duplicated to leverage and sustain the country's development of science and technology, the creation of new commercial products and the provision of quality services, as to improve and consolidate Ecuador's competitive position in the everyday more globalized and modernized world. Private companies should improve their communication with academia, and vice versa, in order that they adjust their academic programs based on the existing business demand as well as firms should include R\&D in their business model. This will guarantee that companies possess the needed intellectual capital. The government should create or modify public policies that support foreign investment, and facilitate companies to benefit from loans that allows them to be more competitive, and help them to generate products and quality services. The Ecuadorian government should make new alliances with other governments to exchange knowledge and skilled workers, as the U.S. government established agreements and alliances with different countries, such as South Korea, Russia, China, Germany, among others. Overall, it is advisable that state and institutional policies are modernized and targeting on a closer tie between the three sectors of the Triple Helix, to facilitate a greater and continuous flow in the generation and transfer of knowledge between the three sectors.

\section{ACKNOWLEDGMENT}

The authors like to express gratitude to Professor Suleiman Kassicieh (PhD) and Professor Raul Gouvea $(\mathrm{PhD})$ of the University of New Mexico, Albuquerque, for their constructive feedback and comments that improved the content of this article.

\section{REFERENCES}

Araque, W., 2013. Creatividad e innovación, una fuente clave de ventaja competitiva para emprendedores y las PYME. Paper Universitario, Universidad Andina Simón Bolivar, 9 pp. Available at http://utelvt.edu.ec/centrodedesarrollo/portafolio/boletines/LINK4.pdf. 
Arnal, E., W. Ok, R. Torres, 2001. Knowledge, work organization and economic growth. OECD Labour Market and Social Policy Occasional Papers, 50, 81 pp. Available at http://www.oecdilibrary.org/social-issues-migration-health/knowledge-work-organisation-and-economicgrowth_302147528625?crawler=true.

Baller, S., S. Dutta, B. Lanvin, 2016. The global information technology report 2016: Innovating in the digital economy. World Economic Forum and INSEAD. New York, $306 \mathrm{pp}$. Available at http://www3.weforum.org/docs/GITR2016/WEF_GITR_Full_Report.pdf.

Banco Mundial, 2015. Ecuador en cifras. Retrieved from http://www.bancomundial.org/ es/country/ecuador.

Barreto, K.S., S.Z. Jara, 2015. Índice global de emprendimiento y desarrollo (GEDI): Un analisis regional para Chile. Universitas: Gestão E TI, 5(1), $7 \mathrm{pp}$. Available at http://www.publicacoesacademicas.uniceub.br/index.php/gti/article/download/3405/2739.

Castells, M., P. Hall, 1994. Technopoles of the world: The making of 21 st century industrial complexes. London, UK: Routledge.

Dueñas, D., E. Duque, 2015. Calidad de las relaciones universidad - empresa: un análisis desde el enfoque de marketing relacional en Boyacá. Revista Científica: Pensamiento y Gestión, 38, 29 pp. Available at http://rcientificas.uninorte.edu.co/index.php/pensamiento/ article/viewFile/7704/7208.

Etzkowitz, H., 2011. Silicon Valley: The sustainability of an innovative region. Commercialising University Research Workshop, University of London Birkbeck, Centre for Innovation, 25 pp.

Etzkowitz, H., L. Leydesdorff, 1995. The Triple Helix: University - Industry - Government relations: A laboratory for knowledge-based economic development. EASST Review, 14(1), 14-19.

Feyen, J., M. Milia, H.B. Van Hoof, K. Quinde, V. Ochoa, V. Abril, J. Bojorque, 2016. Improving the publication visibility of Ecuador's higher education system. MASKANA, 7(2), 113-125.

Figueiredo, P.N., 2008. Industrial policy changes and firm-level technological capability development: evidence from Brazil. World Development, 36(1), 55-88.

GEDI, 2016. Ecuador. Retrieved from https://thegedi.org/countries/Ecuador.

Gouvea, R., S. Kassicieh, 2012. Bridging the innovation divide: The Brazilian experience. Thunderbird International Business Review, 54(3), 275-289.

Instituto Ecuatoriano de Propiedad Intelectual, 2016. Propiedad intelectual. Retrieved from http://www.propiedadintelectual.gob.ec/.

Lall, S., 2004. Reinventing industrial strategy: The role of government policy in building industrial competitiveness. United Nations Conference on Trade and Development, G24 - Discussion Paper Series, New York and Geneva, 46 pp. Available at http://unctad.org/en/Docs/ gdsmdpbg2420044_en.pdf.

Lucas, R.E., 1988. On the mechanics of economic development. Journal of Monetary Economics, 22, 3-42.

Malecki, E.J., 1997. Technology and economic development: The dynamics of local, regional and national change. University of Illinois at Urbana-Champaign's Academy for Entrepreneurial Leadership Historical Research Reference in Entrepreneurship. Retrieved from http://ssrn.com/abstract=1496226.

Melkers, J., D. Bugler, B. Bozeman, 1993. Technology transfer and economic development. In: Bingham, R.D., R. Mier (Eds.), Theories of Local Economic Development: Perspectives from Across the Disciplines ( $2^{\text {nd }}$ ed.). Washington D.C.: SAGE Publications, Inc.

Ministerio de Telecomunicaciones y de la Sociedad de la Información, 2014. Tecnologías de la información y comunicaciones para el desarrollo. Quito, Ecuador.

MINTEL, 2014. De la evolución a la revolución: La sociedad de la información avanza en Ecuador. Quito, Ecuador, 7 pp. Available at http://www.telecomunicaciones.gob.ec/wpcontent/uploads/downloads/2014/07/3ra-semana-telecomunicaciones.pdf.

Pervaiz K,A., C.D. Shepherd, L. Garza, C. Garza, 2012. Administración de la innovación (1ra. ed.). 
México D.F., México: Pearson.

Phillips, R., 2002. Technology business incubators: How effective as technology transfer mechanisms? Technology in Society, 24(3), 299-316.

Pineda, E., C. Gonzalez, 2016. Networking skills in Latin America. IDC, 32 pp. Available at http://www.cisco.com/assets/csr/pdf/IDC_Skills_Gap_-_LatAm.pdf.

Porter, M., 1998. Clusters and the new economics of competition. Harvard Business Review, 76(6), $77-90$.

Powell, W., K. Snellman, 2004. The knowledge economy. Annual Review of Sociology, 30, 199-220.

Powers, J.B., P.P. McDougall, 2005. University start-up formation and technology licensing with firms that go public: a resource-based view of academic entrepreneurship. Journal of Business Venturing, 20(3), 291-311.

Prometeo, 2016. ¿Qué es Prometeo? / What is Prometeo? Retrieved from $\mathrm{http} / / /$ prometeo.educacionsuperior.gob.ec/que-es-prometeo/.

Rao, A., P. Scaruffi, 2011. A history of Silicon Valley: The largest creation of wealth in the history of the planet. México D.F., México: Omniware.

Revista Líderes, 2015. Una alianza promueve la innovación en el Ecuador. Revista Líderes.

The World Bank, 2016. Ecuador. Retrieved from http://www.worldbank.org/en/country/ecuador

Toasa, P., 2015. A la luz y a la sombra de Yachay Tech. Karlsruher Institut fur Technologie. Available at https://stahl.vaka.kit.edu/downloads/Toasa_Yachay_Tech.pdf, 5 pp.

Walsh, S.T., B. Kirchhoff, 2002. Technology transfer from government labs to entrepreneurs. Journal of Enterprising Culture, 10(2), 133-149.

Wessner, C.W., 2014. Growing innovation clusters for American prosperity. Summary of a Symposium. Washington D.C.: National Academies Press.

Wyss, J., 2014. Ecuador is betting $\$ 1$ billion that a dream city can make it a high-tech leader. Miami Herald, July, 2014. Available at http://www.miamiherhald.com/news/nationworld/world/americas/article1975363.html, 5 pp.

Zoltan J,A., P. Correa, 2014. Identifying the obstacles to high-impact entrepreneurship in Latin America and the Caribbean. Washington D.C.: World Bank Group.

Zoltan, A., 2005. Regional innovation, knowledge and global change. New York, NY: Routledge Publishing. 